\title{
Purwarupa Sistem Penggabungan Foto Udara Pada UAV Menggunakan Algoritma Surf (Speeded-Up Robust Features)
}

\author{
Farida Dewanti*1, R. Sumiharto ${ }^{2}$ \\ ${ }^{1}$ Prodi Elektronika dan Instrumentasi Jurusan Ilmu Komputer dan Elektronika, FMIPA UGM \\ ${ }^{2}$ Jurusan Ilmu Komputer dan Elektronika, FMIPA UGM \\ e-mail: *1 farida.de@gmail.com, ${ }^{2}$ __sumiharto@ugm.ac.id
}

\begin{abstract}
Abstrak
Purwarupa penggabungan foto udara pada UAV menggunakan algoritma SURF merupakan suatu sistem yang dirancang untuk melakukan penggabungan citra. Citra tersebut adalah citra yang dihasilkan fixed-wings UAV. Keluaran dari sistem ini berupa tampilan citra dengan objek yang lebih luas.

Sistem ini dirancang untuk dapat melakukan penggabungan foto udara dengan menggunakan algoritma SURF, FLANN, RANSAC, dan warpPerspective. Algoritma SURF digunakan sebagai detektor keypoint dari masing-masing input foto. Metode FLANN untuk melakukan pencocokan keypoint yang ditemukan. RANSAC digunakan untuk pencarian matrix homography. Metode warpPerspective digunakan untuk penggabungan kedua input yang memiliki kecocokan keypoint.

Pengujian terdiri dari beberapa jenis variasi antara lain variasi minimal perpotongan, variasi skala dan variasi rotasi. Variasi minimal perpotongan yang menghasilkan nilai minimal perpotongan sebesar $15 \%$ dan jumlah minimal keypoint berkesesuaian antar kedua citra yang dapat digabungkan adalah 5. Variasi rotasi untuk berapapun perbedaan sudut antara kedua citra tetap dapat digabungkan. Variasi skala minimal citra yang dapat digabungkan adalah skala citra yang diperkecil hingga $75 \%$ dari ukuran citra aslinya, dan skala citra yang diperbesar hingga 600\% dari ukuran aslinya untuk maksimal variasi perbesaran skala.
\end{abstract}

Kata kunci-Foto udara, Penggabungan gambar, SURF, FLANN, RANSAC

\begin{abstract}
Prototype of stitching aerial photograph UAV using SURF algorithm is a system that is designed to stitch the image. The image is generated imagery UAV fixed-wings. The output of this system is a display image with a wider object.

This system is designed to be able to merge aerial images by using SURF algorithm, Flann, RANSAC, and warpPerspective. SURF algorithm is used as a keypoint detector from each of the input images. Flann method to perform keypoint matching is found. RANSAC homography matrix used for the search. WarpPerspective method used for merging the two inputs that have a match keypoint.

The test consists of several types of variations such as the intersection of the minimal variation, variation in scale and rotation variations. Variation that produces intersection minimum value of $15 \%$ and a minimum number of keypoint accords between the two images can be combined is 5. Variation of rotation to any angle difference between the two images can still be combined. Minimum scale variations which can be combined image is the image scale is reduced to $75 \%$ of the size of the original image, and the image scale is enlarged to $600 \%$ of its original size to a maximum variation of magnification scale.
\end{abstract}

Keywords-Aerial Photograph, Stitching Images, SURF, FLANN, RANSAC

Received October $24^{\text {th }}, 2014$; Revised February 11 ${ }^{\text {th }}, 2015$; Accepted October $1^{\text {th }}, 2015$ 


\section{PENDAHULUAN}

Desawat bersayap tetap (fixed wing) adalah pesawat udara yang terbang bukan karena gerakan pada sayap. Pesawat sayap tetap terbang saat pesawat melaju melalui udara. Pergerakan pada sayap menghasilkan gaya angkat yang mengangkat pesawat. Pesawat bersayap tetap berbeda dengan pesawat bersayap putar atau ornitroper, yang terbang dengan sayap yang bergerak dan menghasilkan gaya angkat.

Berdasarkan cara terbang pesawat fixed-wing UAV tersebut, maka pengambilan foto udara dilakukan secara bertahap karena tidak memungkinkan pesawat berhenti di suatu tempat hanya untuk mencari posisi yang tepat untuk melakukan pengambilan foto udara. Sehingga foto yang dihasilkan akan memiliki batasan luas tampilan foto yang cukup kecil.

Untuk mendapatkan informasi foto dengan tampilan yang lebih luas dan jelas maka diperlukan teknik penggabungan citra atau yang dikenal dengan mosaic panoramic.

\subsection{Algoritma SURF}

Algoritma yang akan diusulkan adalah menggunakan algoritma SURF, dimana SURF bekerja berdasarkan tiga tahap utama.

\subsubsection{Proses awal}

Mengubah format RGB 24-bit menjadi grayscale 32-bit dengan menghitung nilai representasi citra integral. Representasi citra Integral bias mengurangi waktu komputasi.

\subsubsection{Mendeteksi titik-titik fitur}

Mencari fitur-fitur blob-like pada citra dengan menggunakan matriks Hessian

a. Membentuk piramid citra

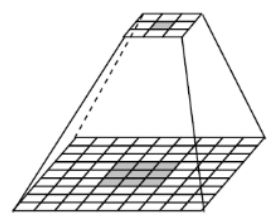

Gambar 1 Struktur piramid [1]

Melakukan konvolusi tapis kotak dengan/ukuran yang semakin besar dengan citra untuk membentuk piramid citra seperti yang tampak pada Gambar 1. Kemudian hasil dari trasformasi piramid citra yang telah dilakukan oleh Chaokui Li ditunjukkan oleh Gambar 2.

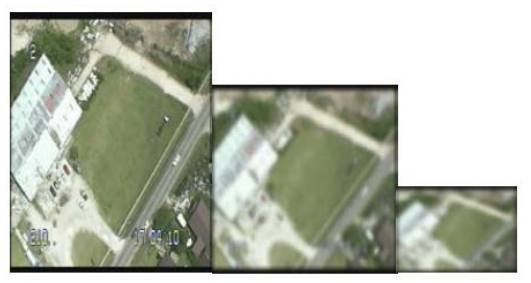

Gambar 2 Trasformasi piramid pada citra [1]

b. Mencari ekstrema dari determinan matriks Hessian

Menghitung nilai dari determinan matriks Hessian kemudian mencari nilai ekstremanya (nilai maksima atau minima dibandingkan dengan nilai-nilai tetangganya). Matriks Hessian di titik $\mathrm{x}=(\mathrm{x}, \mathrm{y})$ dari citra I dengan skala $\sigma$ didefinisikan pada persamaan (1) sebagai berikut: 


$$
H(x, \sigma)=\begin{array}{ll}
\operatorname{Lxx}(x, \sigma) & \operatorname{Lxy}(x, \sigma) \\
\operatorname{Lxy}(x, \sigma) & \operatorname{Lyy}(x, \sigma)
\end{array}
$$

c. Lokalisasi calon fitur

Lokalisasi calon fitur ditentukan dengan metoda-metoda non-maximum suppression pada skala citra tetangganya. Kemudian ekstrema dari determinan matriks Hessian diinterpolasikan pada 3x3x3 skala ruang dengan metoda yang diajukan oleh Brown. Metoda ini akan diterapkan pada setiap calon fitur untuk mencari lokasi extreme setelah diinterpolasi. 3D quadratic menggunakan ekspansi Taylor terhadap fungsi scale-space, $D(x, y, \sigma)$, yang digeser sedemikian rupa sehingga titik origin-nya digunakan sebagai titik uji menggunakan persamaan (2) berikut :

$$
D(\mathrm{x})=D+\frac{\partial D^{T}}{\partial x} x+\frac{1}{2} x^{T}+\frac{\partial^{2} D}{\partial x^{2}} x
$$

dimana, $D$ dan turunan-turunannya dihitung pada titik uji dan $x=(x, y, \sigma) T$ adalah simpangan dari titik uji. Sedangkan lokasi ekstremum dapat dihitung menggunakan persamaan (3) sebagai berikut:

$$
\hat{x}=-\frac{\partial^{2} D^{-1}}{\partial x^{2}} \frac{\partial D}{\partial x}
$$

Jika nilai simpangan $\mathrm{x}$ lebih besar dari 0,5 dalam dimensi manapun, maka ekstremum terletak pada titik lain di dekat titik tersebut. Untuk mencari lokasi ekstremum tersebut, maka titik uji dipindahkan ke titik yang memiliki simpangan lebih dari 0,5 tersebut dan dihitung kembali simpangannya pada titik itu, dan hasilnya dijumlahkan dengan titik uji.

\subsubsection{Pendeskripsian fitur}

Mendeskripsikan titik-titik fitur menggunakan respon Haar wavelet sebagai unit-unit vektor

\section{a. Pemberian orientasi}

Pendeskripsian titik-titik fitur menjadi deskriptor vektor dilakukan agar titik-titik fitur memiliki ketahanan terhadap rotasi, kekontrasan, dan perubahan sudut pandang. Agar tahan terhadap rotasi, maka setiap fitur yang terdeteksi akan diberikan orientasi. Pertama akan dihitung respon Haar-wavelet terhadap sumbu-x dan sumbu-y dengan titik-titik di lingkungan tetangganya pada radius 6s di sekitar titik fitur, dengan s adalah skala pada titik fitur yang terdeteksi. Dengan langkah sampling tiap skala s adalah dari masing-masing skala begitu juga perhitungan respon wavelet-nya sesuai dengan skalanya. Sehingga pada skala yang besar ukuran dari wavelet akan besar pula. Untuk itu akan digunakan perhitungan citra integral untuk pentapisan yang cepat. Dengan demikian hanya dibutuhkan enam operasi untuk menghitung respon pada sumbu-x dan sumbu-y di setiap skala. Lebar dari wavelet adalah 4s.
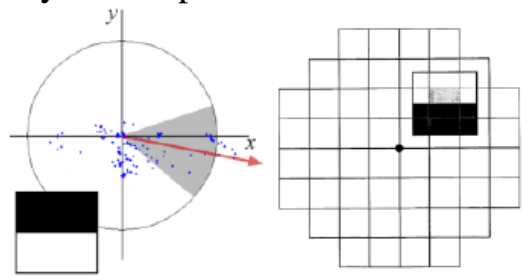

Gambar 3 Pemberian orientasi [2] 
b. Ekstraksi komponen deskriptor

Untuk mengekstraksi deskriptor, langkah pertama yang diambil adalah membuat daerah bujur sangkar yang berpusat di sekitar titik fitur, dan orientasinya mengarah ke orientasi yang sudah ditentukan sebelumnya. Ukuran dari jendela bujur sangkar tersebut adalah $20 \mathrm{~s}$. Contoh gambarnya adalah seperti Gambar 3. Daerah tersebut kemudian dibagi lagi menjadi sub-daerah. Daerah ini tetap berisi informasi ruang sesuai dengan aslinya. Untuk masing-masing sub-daerah ini, akan dihitung beberapa fitur sederhana pada $5 \times 5$ titik sampel ruang. Untuk alasan kesederhanaan, respon Haar-wavelet pada arah horisontal akan disebut dengan $\mathrm{d}_{\mathrm{x}}$ dan respon Haar-wavelet arah vertikal disebut dengan $\mathrm{d}_{\mathrm{y}}$. Yang dimaksud "vertikal" dan "horisontal" dalam hal ini didefenisikan sesuai dengan orientasi dari titik fitur yang bersangkutan. Untuk meningkatkan ketahanannya terhadap deformasi geometrik dan kesalahan lokalisasi, maka respon dan akan dibobot dengan sebuah Gaussian $(\sigma=3,3 \mathrm{~s})$ yang berpusat pada titik fitur.

\subsubsection{Metode Flann}

Metode Fast Library Approximated Nearest Neighbor (FLANN) digunakan untuk matching fitur SURF pada system penggabungan foto udara ini. Fitur SURF ini terdiri dari keypoint dan descriptor dan berupa vektor. Untuk satu gambar di basis data terdapat banyak cluster untuk fitur SURF. Cluster ini dibuat otomatis dengan menggunakan KNN dengan tipe indeks kd tree, dimana KNN ini akan mencari jarak yang paling kecil antara vektor fitur dengan vektor pada cluster [3].

Proses matching atau pencocokan fitur foto udara, vektor keypoint dan deskriptor pada foto udara pertama akan dicocokkan nilainya dengan menggunakan $K N N$ - search. $K N N$-search mencari cluster pada basis data yang nilai vektor deskriptornya paling dekat jaraknya dengan vektor deskriptor pada foto udara kedua. Setelah cluster diperoleh, kemudian akan dicari nilai vektor deskriptor gambar-gambar pada cluster tersebut yang sama atau paling dekat dengan vector deskriptor foto udara pertama. Jika ada yang sama maka ada satu keypoint yang cocok antara kedua gambar tersebut. Selanjutnya, untuk foto udara kedua, dihitung jumlah keypoint yang paling banyak cocok. Jumlah keypoint yang paling banyak cocok yang menghasilkan nilai matches atau kecocokan keypoint yang nantinya akan diproses untuk dihitung matrix homography dan dilakukan proses penggabungan foto udara menggunakan metode warpPerspective.

\subsubsection{Algoritma RANSAC (Random Sample Consensus)}

RANSAC merupakan teknik resampling yang menghasilkan kandidat calon dengan menggunakan minimum jumlah pengamatan (data points) yang diperlukan untuk memperkirakan model parameter secara iteratif untuk sekumpulan data. Algoritma ini diusulkan oleh Fischler dan Bolles pada tahun 1981. RANSAC memberikan estimasi pendekatan parameter umum yang dirancang untuk mengatasi proporsi outlier yang besar dalam data masukan.

Input untuk algoritma RANSAC merupakan seperangkat nilai data yang diamati dan parameter yang dipasang untuk pengamatan yaitu melibatkan pemilihan subset poin acak dari satu set data dan menghitung ukuran seberapa total poin yang konsisten dengan model parameter yang terbentuk dari subset ini dengan probabilitas tertentu. Pada RANSAC, pencapaian hasil terbaik dilakukan dengan menentukan jumlah iterasi yang dilakukan. Algoritma RANSAC bergantung pada ambang jarak (threshold). Ketika poin terbanyak dan konsisten dengan parameter model ini, kemudian dipilih untuk menjadi model estimasi akhir yang dinamakan dengan inliers. Yaitu poin yang kira-kira dapat dipasang ke baris dan outlier yaitu poin yang tidak dapat dipasang ke baris ini. Outlier biasanya muncul dari noise atau dari pengukuran yang keliru atau salah hipotesis tentang interpretasi data [4].

IJEIS Vol. 5, No. 2, October 2015 : 165 - 176 


\section{METODE PENELITIAN}

Rancangan metode penggabungan foto udara menggunakan algoritma SURF ini meliputi perancangan sistem keseluruhan, perancangan pendeteksi fitur menggunakan algoritma SURF dan perancangan pengujian.

\subsection{Rancangan Sistem Keseluruhan}

Rancangan sistem secara keseluruhan merupakan bagian dalam rancangan untuk perencanaan tahap-tahap yang diperlukan untuk membuat program penggabungan foto udara menggunakan algoritma SURF. Program penggabungan foto udara ini dirancang untuk dapat memproses foto yang didapat dari UAV fixed-wings dengan tampilan gambar terbatas, menjadi sebuah keluaran yang menghasilkan tampilan yang lebih luas dengan menggabungkan dengan gambar lain yang berkesesuaian.

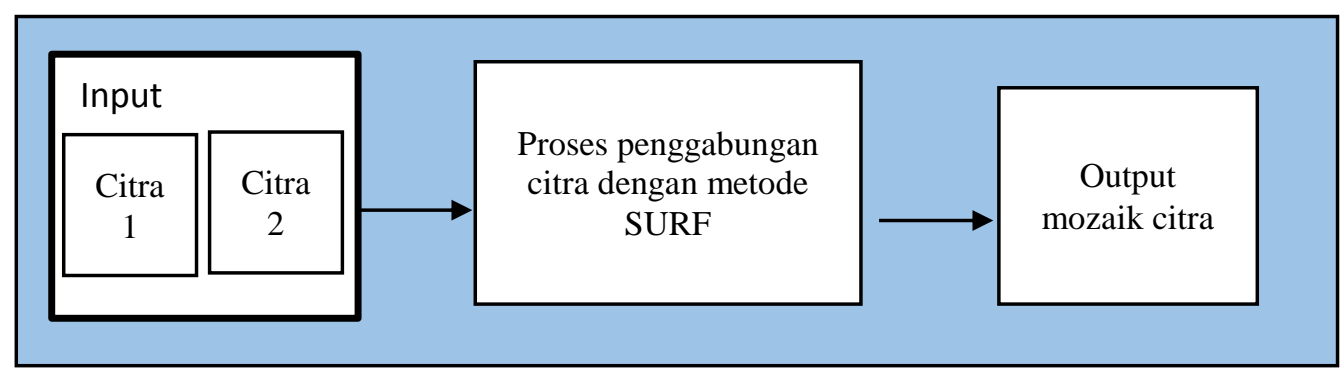

Gambar 4 Blok diagram sistem keseluruhan

Pada Gambar 4 merupakan blok diagram perancangan sistem. Sistem yang akan dibahas pada penelitian ini adalah hanya pada proses penggabungan foto udara yang dilakukan pada komputer. Input berupa foto udara yang diambil melalui kamera yang terpasang pada UAV Fixed-wing. Kemudian setelah input foto udara masuk, maka akan dilakukan proses penggabungan gambar menggunakan algoritma SURF menggunakan komputer. Setelah itu akan menghasilkan keluaran berupa hasil penggabungan gambar yang merupakan foto dengan tampilan yang lebih luas.

\subsection{Perancangan Perangkat Lunak}

Diagram alir secara keseluruhan merupakan suatu tahap-tahap yang dilalui dalam proses penggabungan foto udara mulai dari input foto hingga menghasilkan keluaran mozaik citra.

Gambar 5 merupakan diagram alur proses keseluruhan pada program penggabungan foto udara menggunakan algoritma SURF. Tahapan pertama pada penelitian ini adalah melakukan pencarian titik khas atau keypoint dari masing-masing citra masukan dengan menggunakan metode SURF. Proses selanjutnya yaitu pencarian titik-titik yang berkesesuaian antara kedua citra masukan dengan melihat titik-titik khas pada masing-masing citra masukan. Setelah didapat titik-titik yang berkesesuaian dari kedua citra masukan kemudian dilakukan proses mosaic yaitu proses meñata ulang tiap piksel pada masing-masing citra masukan menggunakan metode transformasi geometri perspektif, yakni proses menata ulang tiap piksel menurut acuan tertentu, acuan yang dipakai dalam penelitian ini adalah keypoint yang berkesesuaian antara kedua citra masukan. Dan tahap terakhir adalah penggabungan dua buah citra masukan menjadi mozaik citra menggunakan librari warpPerspektive. Metode warpPerspektive bekerja dengan cara melakukan transformasi geometri pada input citra kedua agar input citra kedua terproyeksi mirip dengan input citra pertama. 


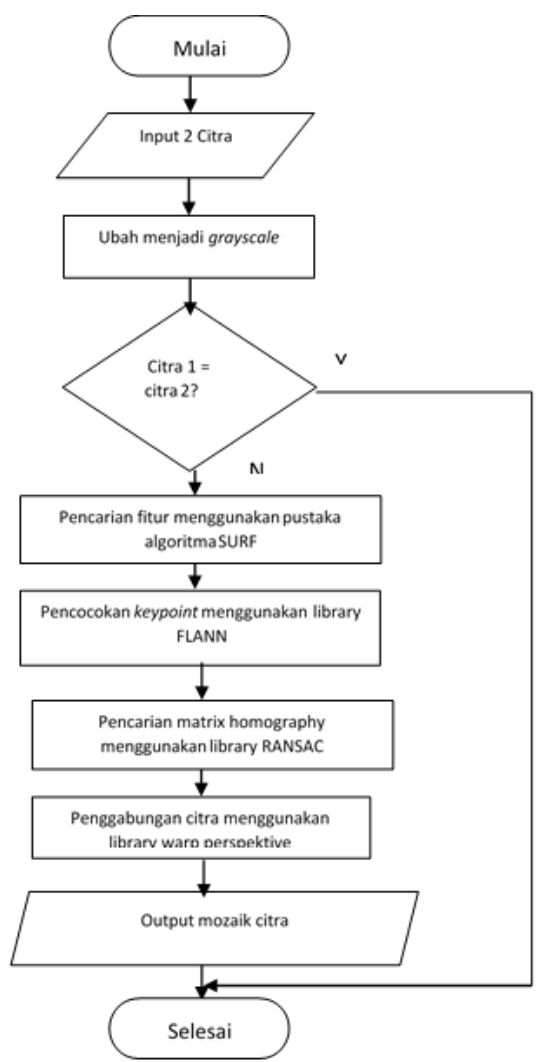

Gambar 5 Bagan alir keseluruhan sistem penggabungan gambar

\section{HASIL DAN PEMBAHASAN}

Tahapan penelitian selanjutnya adalah dengan melakukan pengujian pada sistem penggabungan foto udara menggunakan algoritma SURF. Dalam pengujian ini terdapat beberapa tahapan pengujian, antara lain, pengujian minimal keypoint yang dapat digabungkan, pengujian terhadap minimal persentase perpotongan citra yang dapat digabungkan, pengujian rotasi citra dan pengujian skala citra.

\subsection{Pengujian terhadap minimal jumlah keypoint berkesesuaian yang dapat ditautkan}

Pengujian ini dimaksudkan untuk mengetahui berapa jumlah minimal keypoint yang berkesesuaian antara kedua input yang dapat digabungkan. Pengujian dilakukan dengan beberapa cara. Cara yang pertama adalah dengan cara memotong satu citra utuh menjadi dua bagian hingga membentuk irisan 10\%, kemudian dilakukan pencocokan keypoint sama kedua citra tersebut. Maka menghasilkan jumlah keypoint sama yang berkesesuaian adalah sejumlah 5 keypoint berkesesuaian, ketika dilakukan proses pentautan maka menghasilkan mozaik citra namun kurang sempurna. Cara selanjutnya adalah dengan memotong foto menjadi dua bagian kemudian salah satu bagian dilakukan perbesaran sebesar 650\% lebih besar dari gambar aslinya, kemudian dilakukan penggabungan antara kedua gambar tersebut.

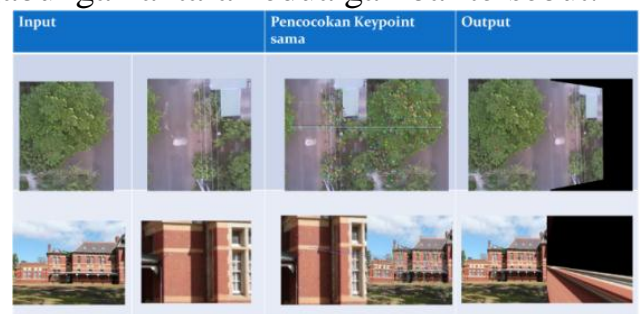

Gambar 6 Pengujian terhadap jumlah minimal keypoint berkesesuaian 
Gambar 6 menunjukkan hasil pencocokan keypoint yang berkesesuaian antar kedua citra. Pada Gambar 6 bagian bawah, jumlah keypoint berkesesuaian yang terdeteksi sejumlah 4 keypoint. Namun untuk hasil penggabungan tidak menghasilkan gabungan yang sesuai. Sehingga untuk penggabungan foto yang dapat digabungkan adalah dengan memiliki syarat minimal keypoint sama adalah sebanyak lima keypoint yang berkesesuaian antar kedua citra yang akan digabungkan.

\subsection{Pengujian terhadap minimal titik potong citra yang dapat ditautkan}

Pengujian ini dimaksudkan untuk mengetahui seberapa minimalkah perpotongan citra yang dapat digabungkan. Pengujian dilakukan dengan cara memotong suatu citra menjadi 2 bagian dengan variasi persentase perpotongan yang berbeda-beda. Pada pengujian ini dilakukan variasi persentase 50\%, 30\%, 15\% dan 10\% untuk masing - masing perpotongan. Pengujian variasi pertama dengan menggunakan sebuah foto udara yang dipotong menjadi 2 bagian dengan perbandingan perpotongan 75\%:75\% sehingga akan menghasilkan titik potong sebesar $50 \%$. Untuk selanjutnya dibuat perpotongan sebesar 55\%:75\% sehingga menghasilkan presentase perpotongan sebesar 30\%. Pengujian ketiga menggunakan nilai perpotongan sebesar 15\% dengan perpotongan gambar pada masing-masing input sebesar 40\%:75\%. Dan yang terakhir menggunakan variasi perpotongan gambar $10 \%$ dengan perpotongan masing-masing citra sebesar 55\%:55\%. Data hasil penggabungan dapat dilihat pada Tabel 1 berikut:

Tabel 1 Tabel pengujian minimal titik potong citra yang dapat digabung

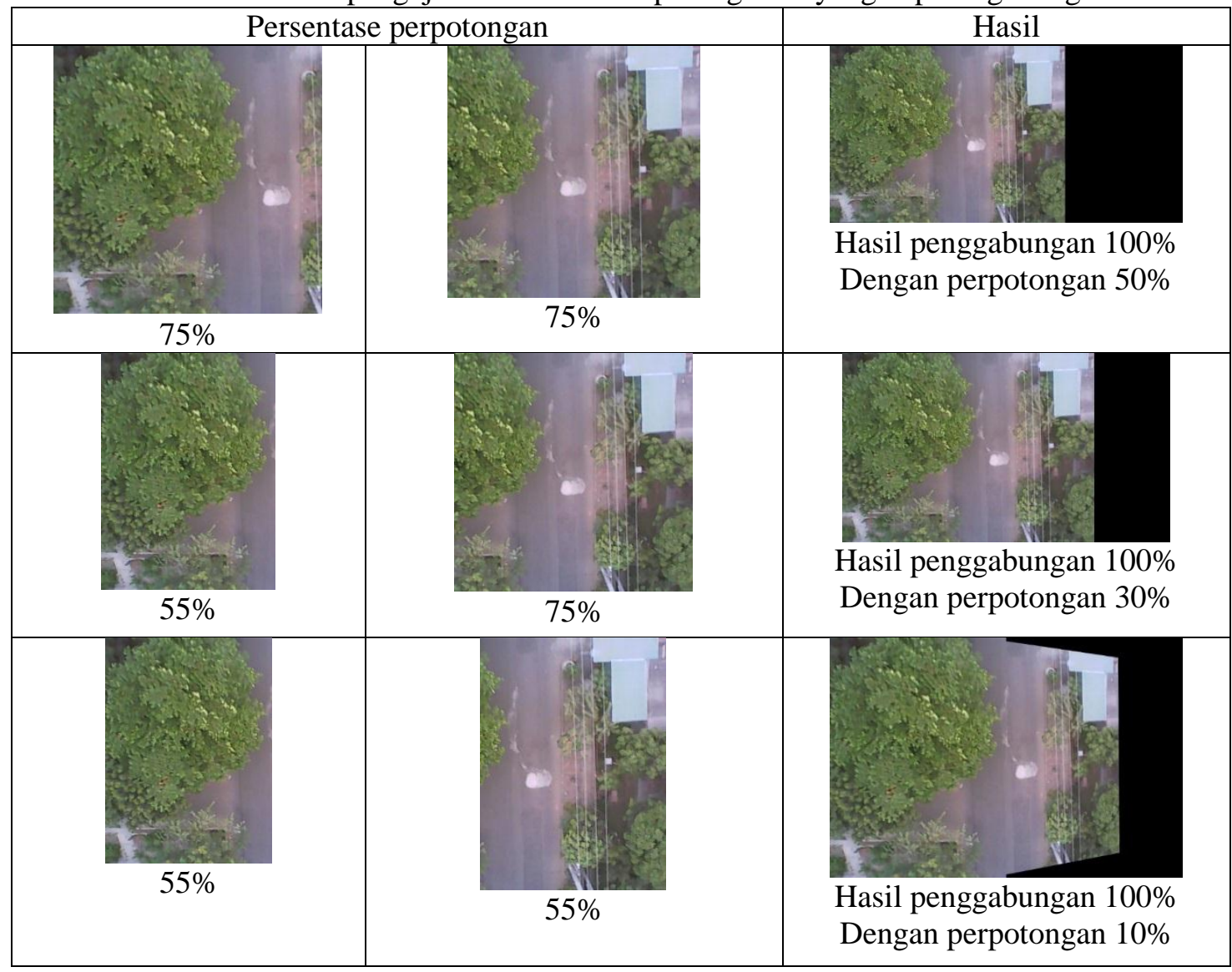

Tabel 1 merupakan hasil pengujian pada sistem penggabungan foto udara menggunakan algoritma SURF dengan menguji seberapa minimalkah titik perpotongan kedua input yang masih dapat tergabung menggunakan sistem yang telah dibuat. Dari hasil tersebut dapat dilihat 
bahwa perpotongan 50\%, 30\% masih dapat dilakukan penggabungan citra oleh sistem. Namun untuk perpotongan $10 \%$ sudah tidak menghasilkan output citra dengan sempurna karena minimnya perpotongan kedua citra input yang menyebabkan sistem hanya menemukan sedikit keypoint yang sama antara kedua input.

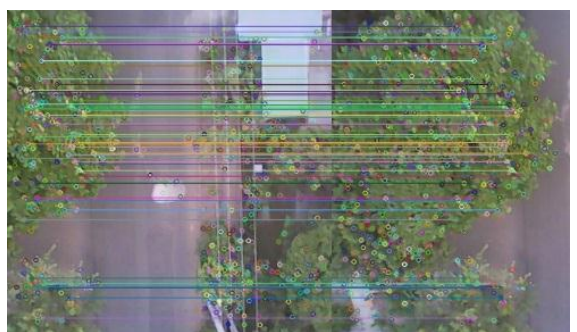

Gambar 7 Hasil pencocokan keypoint untuk perpotongan gambar 30\%

Semakin besar persentase perpotongan input maka nilai keypoint sama antar citra yang ditemukan pun semakin banyak sehingga dapat menghasilkan hasil penggabungan gambar yang semakin baik dibandingkan dengan penggabungan gambar yang hanya menggunakan input dengan persentase perpotongan gambar yang kecil. Pada Gambar 7 merupakan hasil keluaran untuk pencocokan keypoint yang sama, dapat dilihat bahwa keypoint sama yang ditemukan berjumlah lebih banyak dibandingkan dengan jumlah keypoint sama untuk hasil pencocokan pada input dengan variasi perpotongan yang kecil, seperti yang terlihat pada Gambar8yang merupakan hasil dari pencocokan keypoint yang saling sesuai untuk variasi perpotongan input sebesar $10 \%$.

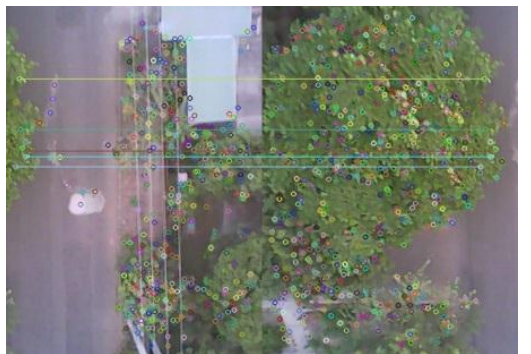

Gambar 8 Hasil pencocokan keypoint untuk perpotongan gambar 10\%

\subsection{Pengujian terhadap rotasi}

Tujuan pengujian ini adalah untuk mengetahui seberapa derajadkah citra yang berotasi dapat digabungkan oleh sistem. Pengujian dilakukan dengan merotasi salah satu input citra dengan beberapa variasi sudut rotasi. Sudut rotasi yang dilakukan variasi adalah $20^{\circ}, 90^{\circ}, 180^{\circ}$, dan $-90^{\circ}$

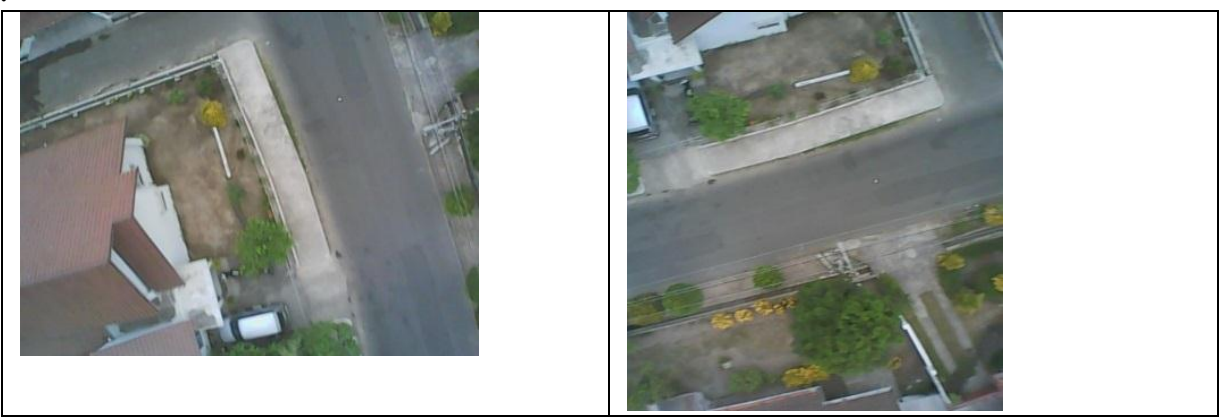

Gambar 9 Input pertama dengan posisi normal (kiri) Input kedua dengan rotasi $90^{\circ}$ (kanan) 


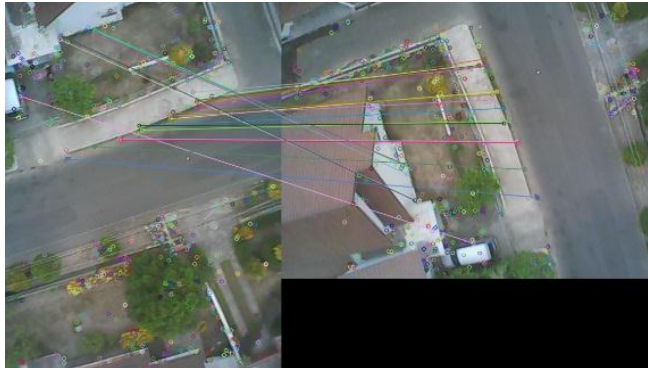

Gambar 10(a) Hasil pencocokan keypoint

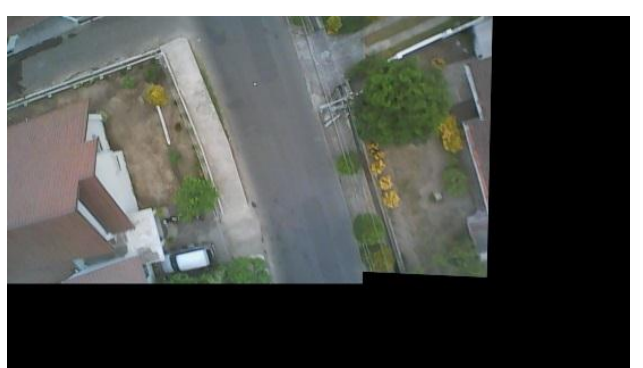

Gambar 10(b)Hasil penggabungan

Pada Gambar 9 merupakan input untuk kedua citra dengan salah satu inputnya dibuat variasi sudut dengan cara merotasinya sebesar $90^{\circ}$ searah jarum jam. Untuk input pertama dibuat normal, sehingga menghasilkan hasil pencocokan keypoint seperti pada Gambar 10(a) Algoritma SURF tetap mendeteksi keypoint walaupun posisi citra mengalami rotasi, sehingga dapat dicari titik-titik yang sama melalui kesamaan keypoint antar kedua citra input. Gambar 10(b) menunjukkan hasil output citra yang telah tergabung, dengan menggunakan perhitungan matrix homography yang dilakukan oleh algoritma RANSAC. Kemudian teknik penggabungan menggunakan warpPerspective, teknik ini melakukan transformasi perspektif pada citra kedua sehingga mirip dengan citra pertama kemudian dilakukan penumpukan citra untuk keypoint yang sama antara kedua input. Oleh sebab itu citra dapat digabungkan walaupun dengan perbedaan input dengan sudut yang dirotasi berapapun karena SURF dapat mendeteksi keypoint walaupun berubah-ubah rotasinya. Metode warpPerspective juga dapat melakukan transformasi perspektif sehingga sudut pandang input kedua dibuat mirip dengan sudut pandang input pertama.

\subsection{Pengujian terhadap skala}

Pengujian ini bertujuan untuk mengetahui seberapa besar perbedaan skala yang masih dapat dilakukan penggabungan. Pengujian ini dilakukan dengan cara mengubah skala atau ukuran salah satu input menjadi ukuran yang berbeda dengan input yang pertama. Pada pengujian pertama dilakukan variasi skala sebesar $50 \%$ lebih kecil dibandingkan ukuran sebenarnya.

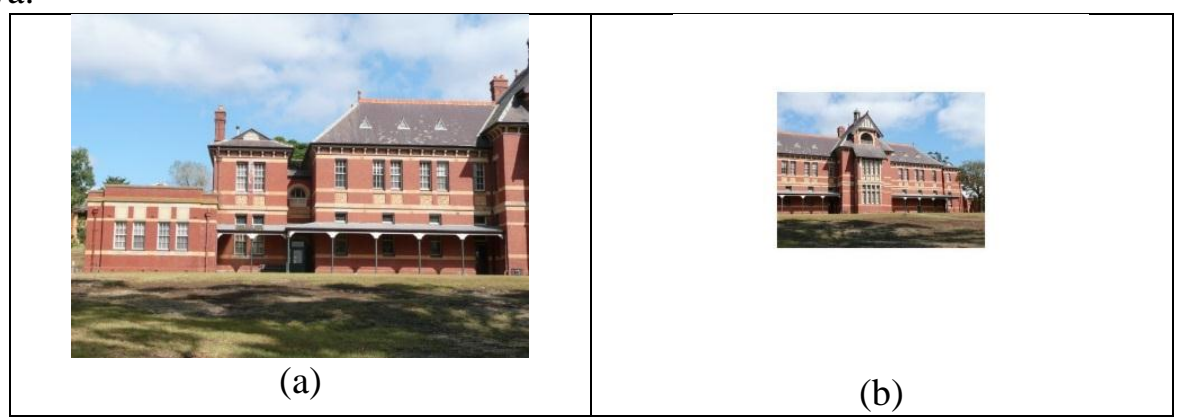

Gambar 11 Input gambar untuk variasi skala 50\%

Gambar 11 merupakan input untuk pengujian terhadap skala yang memiliki perbandingan skala sebesar 50\%, Gambar (a) memiliki ukuran normal, kemudian Gambar (b) memiliki ukuran skala yang lebih kecil 50\% dari ukuran yang sebenarnya. Pada pengujian ini masih ditemukan pencocokan keypoint antara kedua input, walaupun jumlah keypoint yang sama tidak sebanyak input yang memiliki perbandingan skala yang sama. Gambar 12 menunjukkan hasil keluaran untuk pencocokan keypoint antara kedua input dengan variasi skala 50\%. Kemudian Gambar 13 menunjukkan hasil penggabungan gambar untuk perbedaan skala, dari hasil dapat dilihat bahwa gambar yang dihasilkan agak sedikit blur untuk gambar yang diperkecil skalanya, karena pada proses penggabungan dilakukan perbesaran gambar yang kecil disesuaikan dengan besar skala pada input pertama. 


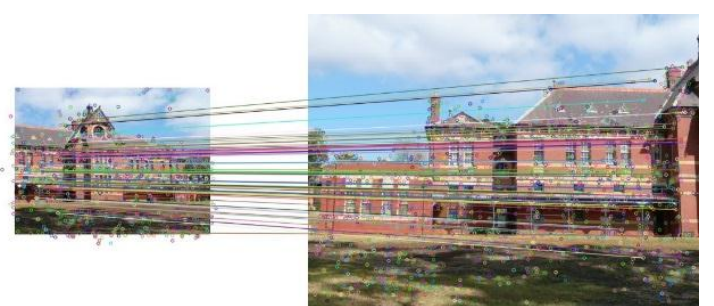

Gambar 12 Hasil pencocokan keypoint untuk variasi skala 50\%

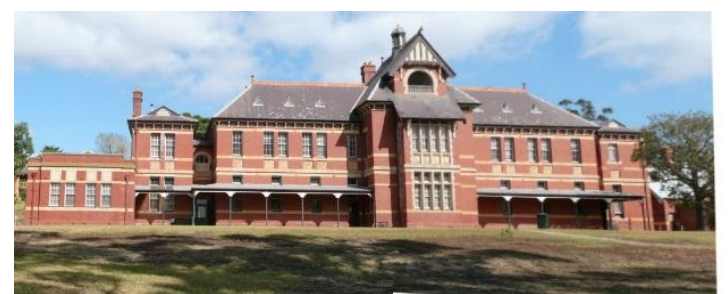

Gambar 13 Hasil penggabungan gambar untuk variasi skala 50\% lebih kecil dari gambar aslinya

Pengujian variasi skala didapatkan nilai skala terkecil untuk dapat digabungkan adalah sebesar 25\% dari citra aslinya. Apabila citra diperkecil lebih dari nilai tersebut maka proses tidak dapat melakukan penggabungan. Untuk pengujian skala yang diperbesar, dilakukan dengan cara memperbesar skala pada salah satu input. Gambar 14 menunjukkan input dengan variasi salah satu inputnya diperbesar $200 \%$.

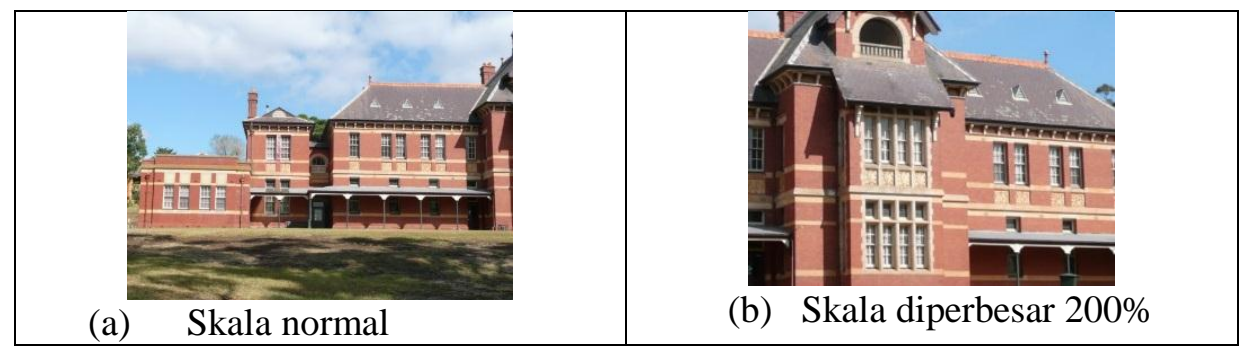

Gambar 14 Input citra dengan variasi perbesaran skala $200 \%$

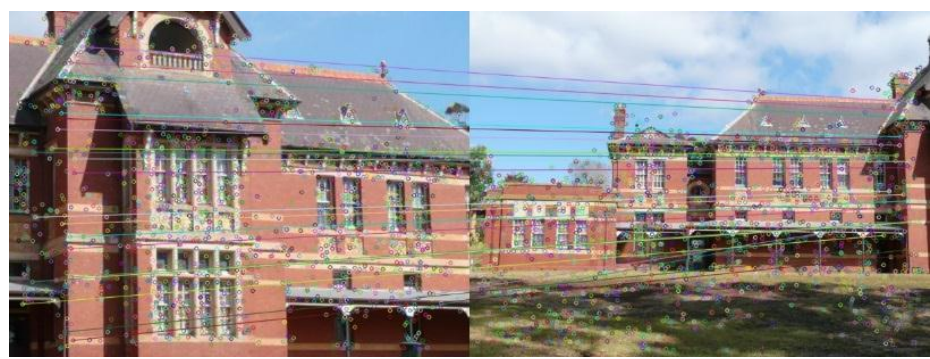

Gambar 15 Hasil pencocokan keypoint untuk variasi perbesaran skala 200\%

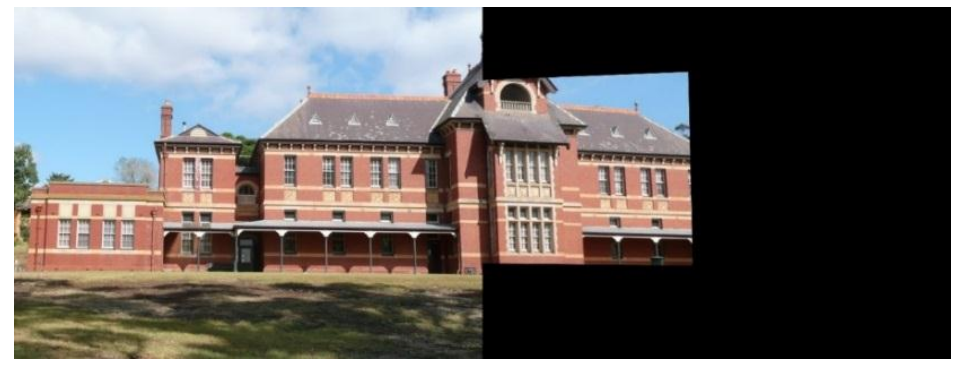

Gambar 16 Hasil penggabungan dengan variasi perbesaran skala 200\% 
Pengujian terhadap perbesaran sebesar 200\% masih dapat dilakukan penggabungan. Gambar 15 menunjukkan bahwa walaupun skala citra berbeda antar kedua input tetapi tetap dapat delakukan pencocokan keypoint yang berkeseuaian karena fitur SURF masih tetap dapat menemukan keypoint walaupun terjadi perubahan skala. Gambar 16 menunjukkan hasil penggabungan kedua citra dengan nilai skala yang berbeda. Pada bagian kiri gambar terlihat seperti terpotong, hal tersebut terjadi karena luasan citra asli yang diperbesar sehingga menghasilkan luasan pandang yang lebih kecil, kemudian citra yang diperbesar mengalami pengecilan skala yang disesuaikan dengan skala pada input citra pertama.

Pengujian variasi perbesaran skala mendapatkan hasil maksimal perbesaran skala citra yang dapat digabungkan adalah $600 \%$ diperbesar dari citra aslinya. Lebih dari itu citra sudah tidak dapat digabungkan karena akan menghasilkan jumlah keypoint yang berkesesuaian lebih sedikit, mengingat jumlah keypoint berkeseuaian yang dapat digabungkan adalah berjumlah 5 keypoint. Untuk perbesaran skala $650 \%$ akan menghasilkan jumlah keypoint berkesesuaian sejumlah 4 keypoint sehingga citra sudah tidak dapat digabungkan.

Dari hasil pengujian yang ditampilkan dapat dilihat bahwa perbedaan skala tidak mempengaruhi algoritma SURF untuk mendeteksi keypoint pada masing-masing citra, sehingga dapat dicari kesamaan keypoint-nya menggunakan metode FLANN. Untuk ukuran variasi input citra yang lebih kecil, ketika diproyeksikan mengikuti citra pertama, akan menghasilkan citra yang blur sehingga penggabungan citra menghasilkan output dengan tampilan yang blur pada bagian input citra yang diperkecil.

\section{KESIMPULAN}

Dari penelitian dan analisis sitem penggabungan foto udara menggunakan algoritma SURF maka dapat disimpulkan bahwa:

1. Telah dibuat sistem penggabungan foto udara menggunakan algoritma SURF sebagi pendeteksi fitur pada suatu citra, metode FLANN sebagai metode pencocokan keypoint yang sama antar kedua input, RANSAC untuk menghitung matrix homography dan warpPerspective untuk penggabungan citra.

2. Minimal perpotongan foto yang dapat digabungkan dengan baik adalah $15 \%$, untuk perpotongan kurang dari 15\% akan menghasilkan gambar output yang kurang sempurna atau ada bagian yang hilang.

3. Minimal keypoint berkesesuaian antara kedua citra input untuk dapat digabungkan adalah 5 keypoint berkesesuaian.

4. Berapapun perbedaan rotasi antar kedua citra input, tetap dapat digabungkan karena algoritma SURF tahan terhadap perubahan rotasi dalam hal mendeteksi keypoint.

5. Perbedaan skala yang dapat dilakukan penggabungan adalah skala citra yang diperkecil hingga $25 \%$ dan skala citra yang diperbesar hingga $600 \%$.

\section{SARAN}

Beberapa saran dari penulis untuk mengembangkan sistem penggabungan foto udara menggunakan algoritma SURF.

1. Diperlukan penelitian lebih lanjut untuk melakukan penggabungan citra lebih dari dua citra dengan tetap mempertahankan kualitas resolusi citra.

2. Diperlukan penelitian lebih lanjut untuk melakukan penggabungan citra dengan perbedaan skala dengan tetap memperhatikan kualitas citra.

\section{UCAPAN TERIMA KASIH}

Penulis mengucapkan terima kasih kepada pihak-pihak yang telah memberi dukungan dan saran serta masukan terhadap penelitian ini. 


\section{DAFTAR PUSTAKA}

[1] Li. Chaokui, Yang. Gang, Wu. Jun and Wang. Fang, 2012. The UAV Video Image Stitching Based on Improved Moravec Corner Matching Method. China

[2] Bay, H., Tuytelaars,T. \& Van Gool, L. (2006) SURF: Speeded Up Robust Features. Proceedings of the ninth European Conference on Computer Vision

[3] Tania, Ken, 2010. Tattoo recognition Based On Speed Up with Robust Feature $(S U R F)$. Risalah Lokakarya Komputasi dalam Sains dan Teknologi Nuklir.

[4] Darajati, Aisah. 2012. Implementasi Dan Analisis Citra Mosaik Berbasis Fitur Dengan Metode Global Alignment Untuk Pembentukan Citra Panorama Pada Android.Fakultas Elektro dan Komunikasi Universitas Telkom. Bandung 